Proc. Estonian Acad. Sci. Geol., 2005, 54, 4, 260-265

\title{
The tube ultrastructure of serpulids (Annelida, Polychaeta) Pentaditrupa subtorquata, Cretaceous, and Nogrobs cf. vertebralis, Jurassic, from Germany
}

\begin{abstract}
Olev Vinn
Institute of Geology, University of Tartu, Vanemuise 46, 51014 Tartu, Estonia; vinn@ut.ee

Received 2 September 2005, in revised form 8 November 2005

Abstract. Calcitic prismatic structures occurred already in Jurassic serpulid tubes, here described in Nogrobs cf. vertebralis. In Cretaceous Pentaditrupa subtorquata (Serpulidae) the external layer of the tube has a semiregular spherulitic prismatic structure closely resembling that in the vitreous tube of recent Placostegus tridentatus but differing from the external hyaline layer of recent Ditrupa arietina (Serpulidae). The internal tube layer of $P$. subtorquata is presumably diagenetically altered and has a granular homogeneous structure. The prismatic structures seem to have the best preservation potential in fossil serpulid polychaetes.
\end{abstract}

Key words: serpulids, tube ultrastructure, fossilization, Jurassic, Cretaceous, Germany.

\section{INTRODUCTION}

The tube ultrastructure of recent calcifying polychaetes has recently been studied by many authors (ten Hove \& Zibrowius 1986; Zibrowius \& ten Hove 1987; ten Hove \& Smith 1990; Nishi 1993; Pillai \& ten Hove 1994; Weedon 1994; Sanfilippo 1996, 1998). Fine complex crossed lamellar (CCL) structure sensu Carter et al. (1990), ordered chevron structure sensu Weedon (1994, p. 5, fig. 2), and various prismatic structures have been described in serpulid polychaetes (ten Hove \& Zibrowius 1986; Zibrowius \& ten Hove 1987). The last authors hypothesize that the vitreous tube layer in serpulids is caused by the regular orientation of long crystals in the tube. Mesozoic serpulid polychaetes are taxonomically well studied (Regenhardt 1961; Lommerzheim 1979; Jäger 1983). The ultrastructure of fossil polychaete tubes has been studied by Zibrowius \& ten Hove (1987), Weedon (1994), Fischer et al. (1989), Fischer et al. (2000), and Schweitzer et al. (2005), but is still inadequately understood. 
To affiliate fossil calcareous tubes of possible polychaetes with recent taxa such as Serpulidae, it is important to know the ultrastructural changes caused by fossilization. The goal of the paper is to find structural similarities in calcareous tubes between living and fossil polychaetes and describe the ultrastructure in Pentaditrupa subtorquata and Nogrobs cf. vertebralis for the first time.

\section{MATERIAL AND METHODS}

The tube of Nogrobs cf. vertebralis from the Middle Bathonian, Jurassic of Blumberg, SW Germany, and Pentaditrupa subtorquata from the Upper Campanian, Cretaceous of Höver by Hannover, Germany, were selected for SEM study. The examined tubes were ground in longitudinal direction, polished, and etched with $1 \%$ acetic acid for 1 min prior to SEM examination. Thereafter, the same tubes were re-polished and treated with a 1:1 mixture of $25 \%$ glutaraldehyde and $1 \%$ acetic acid, to which alcian blue was added (GA-solution), for 5-45 min before SEM study. Energy dispersive X-ray analysis was applied to distinguish calcite from aragonite by a high content of $\mathrm{Mg}$ or by a high content of Sr. All figured and measured specimens are deposited at the Zoological Museum, University of Amsterdam (ZMA) and Museum of Geology, University of Tartu (TUG).

\section{TUBE STRUCTURE IN CRETACEOUS PENTADITRUPA SUBTORQUATA}

This species has a tube composed of two calcitic layers separated by a distinct border. The external layer is $0.20-0.50 \mathrm{~mm}$ thick at a tube diameter of $3.2 \mathrm{~mm}$ and has a semiregular spherulitic prismatic ultrastructure similar to the molluscan spherulitic prismatic structure sensu Carter et al. (1990) (Pl. I, figs. 3, 4). The prisms are $80-160 \mu \mathrm{m}$ long and 6-20 $\mu \mathrm{m}$ wide. The growth layers (growth increments), with an interval of $2-6 \mu \mathrm{m}$, subperpendicular to the prisms, are partially preserved in the external tube layer (P1. I, fig. 3). The $0.10 \mathrm{~mm}$ thick internal layer is composed of calcareous granules and has a homogeneous ultrastructure (Pl. I, fig. 8).

The original structure of the internal tube layer could not be identified in the sample etched with acetic acid and in one treated with the GA-solution. The homogeneous granular structure of $P$. subtorquata is possibly secondary, being very similar to the secondary homogeneous granular matrix in the fossilized Ditrupa internal layer (Zibrowius \& ten Hove 1987, fig. 3E; Weedon 1994, p. 11). Such a structure is known in fossil material, but not in any recent serpulid tube (personal observations). 
PLATE I
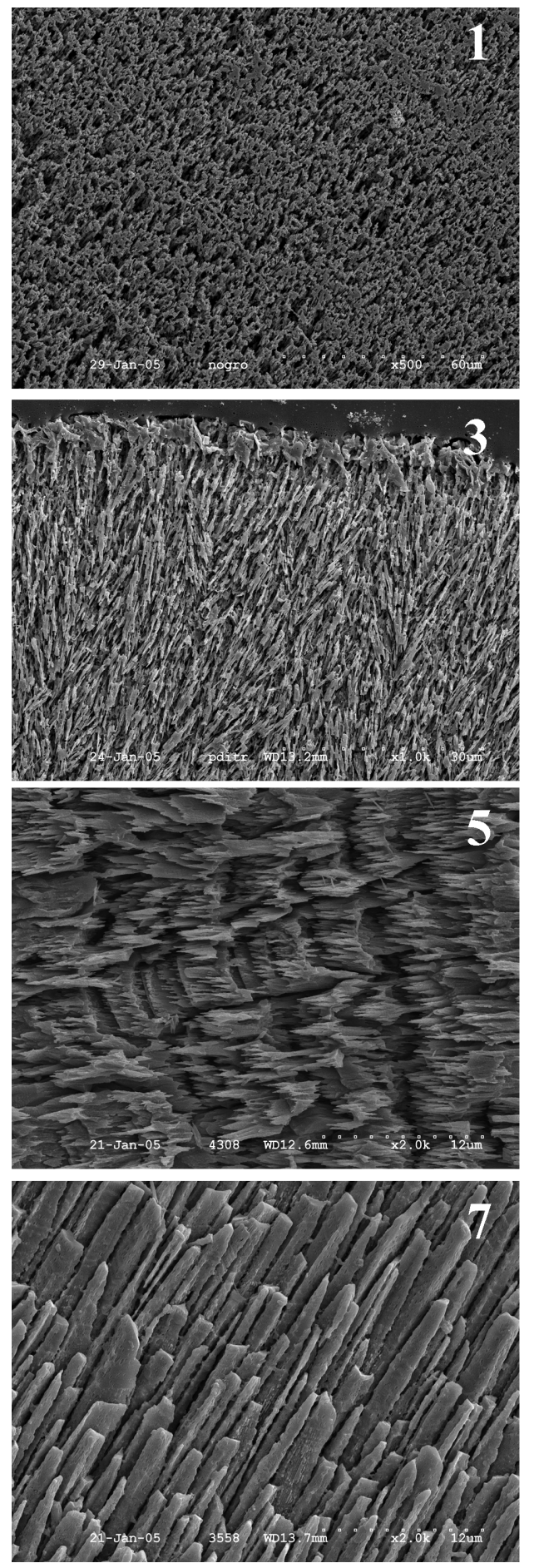

262
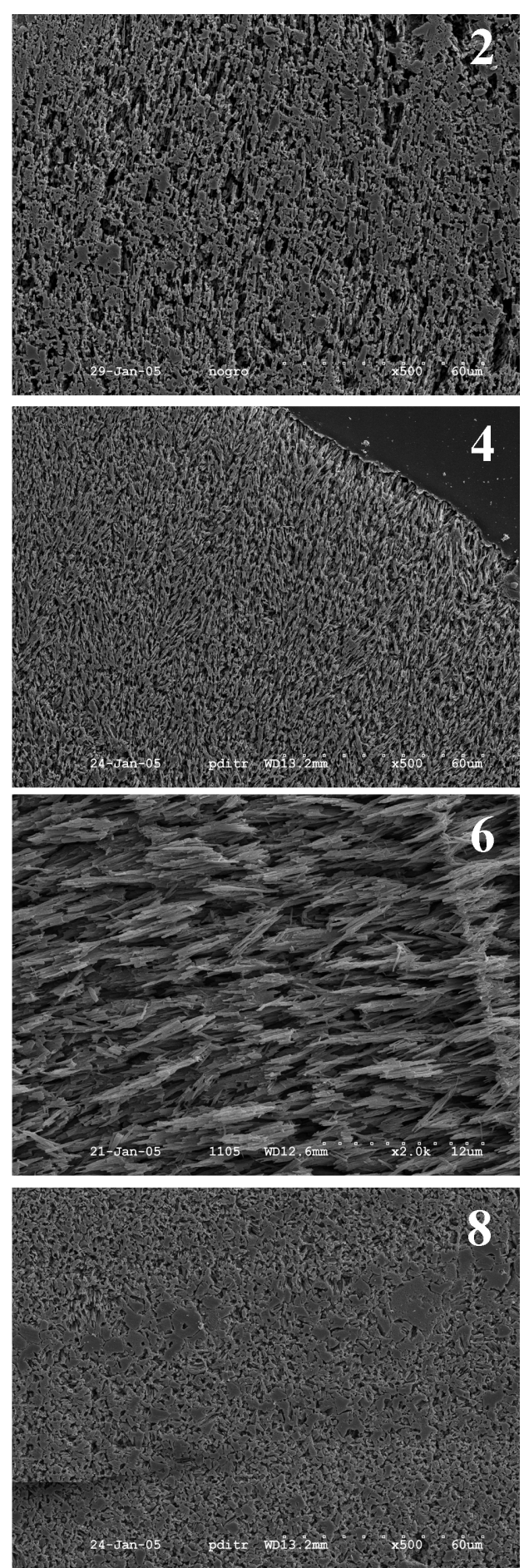


\section{TUBE STRUCTURE IN JURASSIC NOGROBS CF. VERTEBRALIS}

The tube of Nogrobs cf. vertebralis is composed of a single layer with a calcitic prismatic ultrastructure. The prisms are 100-150 $\mu \mathrm{m}$ long and 3-4 $\mu \mathrm{m}$ wide, having a spherulitic arrangement in some places (Pl. I, figs. 1, 2). The prisms appear partially as a negative relief on the polished cross- and longitudinal sections of the tube after treatment with the GA-solution (Pl. I, figs. 1,2). Occasional growth layers perpendicular to the prisms are preserved in the tube wall (Pl. I, fig. 1). The structure of $N$. cf. vertebralis is somewhat similar to the molluscan irregular spherulitic prismatic structure sensu Carter et al. (1990).

\section{DISCUSSION}

The preservation of growth lines (growth increments) perpendicular to the prisms in the tube walls of fossil Pentaditrupa subtorquata (Pl. I, fig. 4) and Nogrobs cf. vertebralis (Pl. I, fig. 1) indicates that these taxa had originally a prismatic tube structure. The semiregular spherulitic prismatic external layer of P. subtorquata (Pl. I, figs. 3, 4) closely resembles the irregular spherulitic prismatic tube structure (sensu Carter et al. 1990) of recent serpulids Placostegus tridentatus (Pl. I, fig. 6) and Vitreotubus digeronimoi (Pl. I, fig. 5), giving further evidence of the ultrastructure of $P$. subtorquata being preserved in its original state. Also, the structure of $N$. cf. vertebralis slightly resembles that of Vitreotubus digeronimoi and Placostegus tridentatus, but has clearly longer prisms.

The tubes of recent Ditrupa arietina are composed of two layers (ten Hove \& Smith 1990). The external hyaline layer (Pl. I, fig. 7) has a structure that resembles the irregular simple prismatic structure of molluscs (Carter et al. 1990), but differs from the semiregular and irregular spherulitic prismatic structure in fossil Pentaditrupa subtorquata and Nogrobs cf. vertebralis in a much larger size and more regular shape of prisms. From the aspect of tube ultrastructure fossil Pentaditrupa does not appear to be closely related to recent Ditrupa.

According to the present study prismatic structures seem to have good preservation potential and may help to link fossil serpulid taxa with recent ones. In contrast, non-prismatic structures, such as ordered chevron structure sensu

\section{Explanation of Plate I}

Figs. 1, 2. Nogrobs cf. vertebralis, irregular spherulitic prismatic structure, Middle Bathonian, Jurassic of Blumberg, SW Germany, ZMA V.Pol. 3811. 1, longitudinal section; 2, cross-section.

Figs. 3, 4. Pentaditrupa subtorquata, semiregular spherulitic prismatic structure, Upper Campanian, Cretaceous of Höver by Hannover, Germany, ZMA V.Pol. 3705. 3, longitudinal section of the external layer; 4, cross-section of the external layer.

Fig. 5. Vitreotubus digeronimoi, irregular spherulitic prismatic structure, longitudinal section, Seychelles, north of Platte Island, ZMA V.Pol. 4308.

Fig. 6. Placostegus tridentatus, irregular spherulitic prismatic structure, longitudinal section, Bergensfjord, Norway, ZMA V.Pol. 1105.

Fig. 7. Ditrupa arietina, irregular simple prismatic structure, cross-section, Tjärnö, Sweden, TUG 1232-1.

Fig. 8. Pentaditrupa subtorquata, homogeneous internal layer, cross-section, ZMA V.Pol. 3705. 

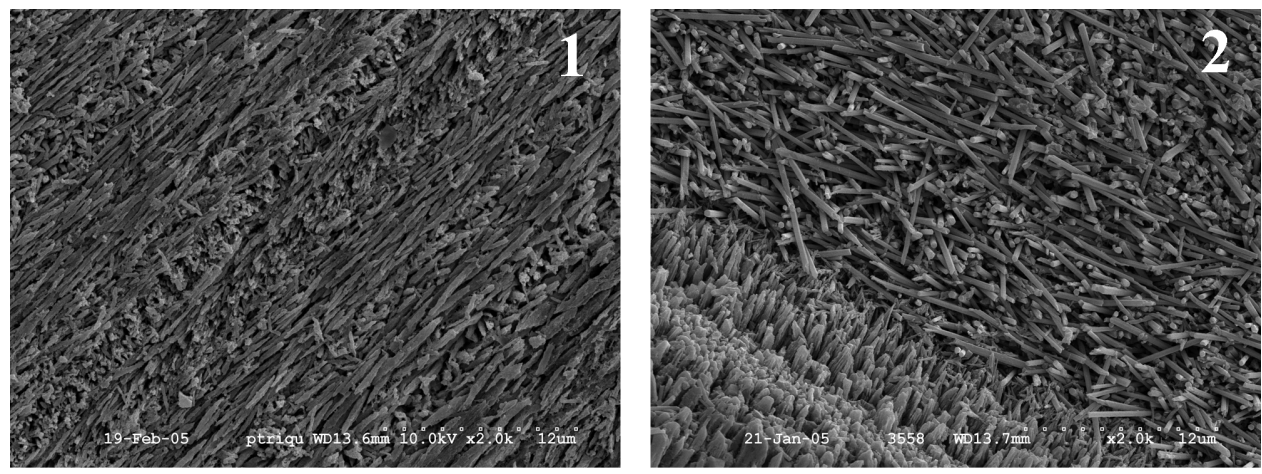

Fig. 1. Tube ultrastructures of recent serpulids. 1, Pomatoceros triqueter, ordered chevron structure sensu Weedon (1994), cross-section, Tjärnö, Sweden, TUG 1232-2; 2, Ditrupa arietina, fine complex crossed lamellar structure of the internal tube layer (upper right), cross-section, Tjärnö, Sweden, TUG 1232-1.

Weedon (1994) in Pomatoceros sp. (Fig. 1.1) and complex crossed lamellar structures (Fig. 1.2) of the internal layer in Ditrupa arietina (Zibrowius \& ten Hove 1987; ten Hove \& Smith 1990), seem to be completely substituted by a homogeneous structure during fossilization. Thus, the serpulid fossils with a prismatic structure may yield more valuable information for the taxonomic and phylogenetic studies than the ones with a secondary homogeneous structure.

\section{ACKNOWLEDGEMENTS}

I am grateful to H. A. ten Hove, Zoological Museum, Amsterdam, who helped with the literature and loaned identified material for the study, and to H. Mutvei and E. Dunca, Swedish Museum of Natural History, for their help with SEM work. I thank H. Mutvei and H. A. ten Hove for constructive review of the paper. I do acknowledge SYNTHESYS support made available by the European Community-Research Infrastructure Action under the FP6 Structuring the European Area Program to the project NL-TAF-111 and SE-TAF-113.

\section{REFERENCES}

Carter, J. G., Bandel, K., de Buffrénil, V., Carlson, S. J., Castanet, J., Crenshaw, M. A., Dalingwater, J. E., Francillion-Vieillot, H., Géradie, J., Meunier, F. J., Mutvei, H., de Riqlès, A., Sire, J. Y., Smith, A. B., Wendt, J., Williams, A. \& Zylberberg, L. 1990. Glossary of skeletal biomineralization. In Skeletal Biomineralization: Patterns, Processes and Evolutionary Trends, Vol. I (Carter, J. G., ed.), pp. 609-671. Van Nostrand Reinhold, New York.

Fischer, R., Galli, O. C. \& Reitner, J. 1989. Skeletal structure, growth, and paleoecology of the patch reef-building polychaete worm Diplochaetetes mexicanus Wilson, 1986 from the Oligocene of Baja California (Mexico). Geobios, 22, 761-775.

Fischer, R., Pernet, B. \& Reitner, J. 2000. Organomineralization of Cirratulid Annelid tubes - fossil and recent examples. Facies, 42, 35-50. 
Jäger, M. 1983. Serpulidae (Polychaeta sedentaria) aus der norddeutschen höheren OberkreideSystematik, Stratigrafie, Ökologie. Geol. Jahrb., A 68, 3-219.

Lommerzheim, A. 1979. Monographische Bearbeitung der Serpulidae (Polychaeta sedentaria) aus dem Cenoman (Oberkreide) am Südwestrand des Münsterländer Beckens. Decheniana, 132, $110-195$.

Nishi, E. 1993. On the internal structure of calcified tube walls in Serpulidae and Spirorbidae (Annelida, Polychaeta). Marine Fouling, 10, 17-20.

Pillai, T. G., \& ten Hove, H. A. 1994. On recent species of Spiraserpula Regenhardt, 1961, a serpulid polychaete genus hitherto known only from Cretaceous and Tertiary fossils. Bull. Nat. Hist. Mus. London (Zool.), 60, 39-104.

Regenhardt, V. H. 1961. Serpulidae (Polychaeta sedentaria) aus der Kreide Mitteleuropas, ihre ökologische, taxionomische und stratigraphische Bewertung. Mitt. Geol. Staatinst. Hamburg, 30, 5-115.

Sanfilippo, R. 1996. Micromorphology, microstructure and functional morphology of the Josephella marenzelleri (Polychaeta, Serpulidae) tube. In Autecology of Selected Organisms: Achievements and Problems (Cherchi, A., ed.), Boll. Soc. Paleontol. Ital., Spec. Vol., 3, 205-211.

Sanfilippo, R. 1998. Tube morphology and structure of the bathyal Mediterranean serpulid Hyalopomatus variorugosus Ben-Eliachu \& Fiege, 1996 (Annelida, Polychaeta). Riv. Ital. Paleontol. Stratigr., 104, 131-138.

Schweitzer, C. E., Feldmann, R. M., Marenssi, S. \& Waugh, D. A. 2005. Remarkably preserved annelid worms from the La Meseta Formation (Eocene), Seymour Island, Antarctica. Palaeontology, 48, 1-13.

ten Hove, H. A. \& Zibrowius, H. 1986. Laminatubus alvini gen. et sp. n. and Protis hydrothermica sp. n. (Polychaeta, Serpulidae) from the bathyal hydrothermal vent communities in the eastern Pacific. Zool. Scripta, 15, 21-31.

ten Hove, H. A. \& Smith, R. S. 1990. A re-description of Ditrupa gracillima Grube, 1878 (Polychaeta, Serpulidae) from the Indo-Pacific, with a discussion of the genus. Records Austral. Mus., 42, 101-118.

Weedon, M. J. 1994. Tube microstructure of Recent and Jurassic serpulid polychaetes and the question of the Palaeozoic 'spirorbids'. Acta Palaeontol. Polonica, 39, 1-15.

Zibrowius, H. \& ten Hove, H. A. 1987. Neovermilia falcigera (Roule, 1898), a deep- and coldwater serpulid polychaete common in the Mediterranean Plio-Pleistocene. Bull. Biol. Soc. Washington, 7, 259-271.

\section{Koja peenstruktuur serpuliididel (Annelida, Polychaeta) Pentaditrupa subtorquata Kriidist ja Nogrobs cf. vertebralis Juurast Saksamaalt}

\section{Olev Vinn}

Kaltsiitsed prismaatilised struktuurid on kirjeldatud Saksamaalt pärit serpuliididel Pentaditrupa subtorquata Kriidist ja Nogrobs cf. vertebralis Juurast. $P$. subtorquata koja välimisel kihil on poolkorrapärane sferuliitne prismaatiline struktuur, mis sarnaneb tänapäevase serpuliidi Placostegus tridentatus struktuurile ja erineb tänapäevase serpuliidi Ditrupa arietina koja väliskihi struktuurist. Pentaditrupa koja seina homogeense struktuuriga sisekiht on tõenäoliselt diageneetiliselt muutunud. Serpuliidide koja prismaatilistel struktuuridel tundub olevat parim säilimise potentsiaal. 